\title{
Internationalisation Patterns of Polish Family High-Tech Firms
}

\author{
Nelly Daszkiewicz
}

\section{A B S T R A C T}

Objective: The objective of the article is to explore internationalisation patterns of family high-tech firms, especially their internationalisation motives, intensity, speed, and entry modes.

Research Design \& Methods: The empirical part adopts a quantitative approach. The results of the survey are presented on the sample of 263 high-tech production firms from Poland, including 101 family firms. The survey was conducted in all 16 Polish regions. The calculations from obtained survey results were made using Statistica PL 10.

Findings: The research results show that the intensity of internationalisation of family firms is lower than that of non-family enterprises and that family businesses are less likely to internationalise early than in the case of non-family enterprises. On the other hand, the study found no differences between family and non-family businesses in their entry modes choice and internationalisation motives.

Implications \& Recommendations: Familiness is one of the key factors that explain the internationalisation of firms. However, various research findings still differ on how international behaviour of family firms may be different than in the case of nonfamily firms. Thus, the impact of familiness on internationalisation patterns requires further, deeper investigations.

Contribution \& Value Added: The main contribution of this article is that investigates Polish family firms, which are relatively young in comparison to the Western European ones. Moreover, the Polish firms belong to high-tech industries that often behave differently in the foreign markets than firms from traditional branches. The study indicates that familiness is an important aspect relevant in explaining the internationalisation patterns of firms.
Article type: research article
Keywords:
internationalisation; family firms; high-tech firms; international entre- preneurship

JEL codes: $\quad$ F23, L20

Received: 22 September 2019 Revised: 3 November 2019 Accepted: 11 November 2019

\section{Suggested citation:}

Daszkiewicz, N. (2019). Internationalisation Patterns of Polish Family High-Tech Firms. Entrepreneurial Business and Economics Review, 7(4), 147-163. https://doi.org/10.15678/EBER.2019.070409 


\section{INTRODUCTION}

Despite research interest in family firm international expansion has been growing for the last two decades, it still remains a young field of study that seeks a consistent framework. The decision of a family firm to begin international expansion depends on many factors and motives. Unlike non-family firms, family firms are influenced by family relationships that bind family members both to each other and to their business (Daszkiewicz \& Wach, 2014; Lušňáková, Juríčková, Šajbidorová, Lenčéšová, \& Lence, 2019). On the other hand, the main value and competitive advantage of family firms results from family ties (Labaki, 2011; Weclawski \& Zukowska, 2019). Marjański and Sułkowski (2019) explain that family businesses operate on the border between two qualitatively different social institutions: family and business. These two systems overlap in a family firm to form a specific business system that significantly differs from firms which are not controlled by a family.

Thus, the functioning of family firms in many areas differs from non-family firms, including their international expansion. However, there is much evidence in the extant literature that family firms engage in activities that lead them towards foreign markets and that internationalisation is an important strategic element in achieving growth (Stieg, Cesinger, Apfelthaler, Kraus, \& Cheng, 2018; Głodowska, Pera, \& Wach, 2019).

On the other hand, the literature review shows that family firms are more likely to choose a traditional path of internationalisation, which is consistent with the concept of the Uppsala model of internationalisation (Johanson, \& Vahlne, 1977). The stepwise approach of family firms is connected with their long-term orientation to both business and family (Stieg et al., 2018; Brigham, Lumpkin, Payne, \& Zachary, 2014).

However, various research shows mixed results of internationalisation processes of family businesses compared to non-family businesses (Arregle, Duran, Hitt, \& Van Essen 2017; O’Boyle, Pollack, \& Rutherford, 2012).

Verbeke, Yuan, and Kano (2018) also provide arguments that different empirical research produces ambiguous results, ranging from positive to negative to non-linear relationships between the familiness of firms and their internationalisation.

The objective of this article is to explore internationalisation patterns of family firms, especially their motives to go international along with their internationalisation intensity, speed, and entry modes. The main research question is whether family firms internationalise more or less than non-family firms in terms of different aspects of their international behaviour.

The theoretical framework is built on literature review. The empirical part adopts the quantitative approach. The results of the survey are presented on the sample of $263 \mathrm{high}$ tech production firms from Poland, including 101 family firms.

The article contributes to the research on family firm internationalisation by investigating family firms from high-tech industries. There is much evidence in literature that these firms are more internationalised than traditional (low-tech) ones. Moreover, high-tech firms more often begin internationalisation processes from the inception or soon after, and they are more likely to use advanced market entry modes to enter new markets (Daszkiewicz, 2019). Moreover, Polish family firms are relatively young in comparison to their Western European counterparts and, thus, may behave differently on foreign markets (Hadryś-Nowak, 2018). 
The article consists of literature review of theoretical concepts of family firms internationalization, description of the used research methods and presentation of the research results and discussion. In conclusions directions of further research and implications for practice are included.

\section{LITERATURE REVIEW}

Internationalization is a worldwide process affecting the global economy and society (Hallova et al., 2019; Chalupova et al., 2019). Various research shows different results on how different factors facilitate or constrain the internationalisation of family firms (Arregle et al. 2017). The reason for these mixed results may be because the studies focus on different types of family firms, which are heterogeneous. Thus, their strategic behaviours may differ not only between family and non-family firms but also within family businesses due to their heterogeneity.

Stieg et al. (2018) foreground that several studies find no differences in levels of international behaviour in the case of family firms in comparison with non-family firms (Crick, Bradshaw, \& Chaudhry, 2006), but some others indicate at higher (Graves \& Shan, 2014; Tsao \& Lien, 2013) or lower levels of international performance of family firms (Thomas \& Graves, 2005; Zahra 2003). Moreover, international business research indicates a variety of factors positively associated with international behaviour of family firms, such as education, international experience, commitment, risk propensity, perceived benefits, or market knowledge (Stieg et al., 2018).

Graves and Thomas (2008) state that family firms face unique barriers of internationalisation. They define three particular determinants of internationalisation pathways, which are the degree to which the owning family is committed to internationalisation, the amount of financial resources available for internationalisation, and a firm's ability to develop its potential.

Moreover, family businesses usually do not have sufficient international market knowledge, in particular in the pre-internationalisation phase, as they accumulate knowledge incrementally and slowly and remain reluctant to enter new networks and form new relationships (Stieg et al., 2018). Sciascia, Mazzola, Astrachan, and Pieper (2012) indicate the inverted U-shaped relationship between familiness and internationalisation intensity. In turn, Zahra (2003) states that family involvement in the board of directors positively influences international sales due to the stewardship effect. The effect causes family members want to create conditions for the firm that would last long for the current and future generations.

Kontinen and Ojala $(2010,2012)$ state that familiness may cause cautiousness in a firm's internationalisation process. Hence, family firms are more likely to choose a traditional path of internationalisation. International expansion of family businesses is more often gradual and - in comparison with non-family firms - consistent with the internationalisation process described in the Uppsala model. Moreover, family firms tend to choose psychically close markets and rather indirect than direct entry modes. Furthermore, their behaviour in a foreign direct investment process is less formal than in the case of non-family firms. They also tend to rely on familiar sources about foreign markets information, thus they rely on wellestablished, lasting, and identity-based network ties (Kontinen \& Ojala, 2011). 
Pukall and Calbro (2014) conducted a very wide survey, which reviews 72 articles on various aspects of the internationalisation of family businesses published in 1980-2012. The review shows that the impact of familiness on different aspects of internationalisation (e.g. type of market entry, speed of internationalisation, or degree of international sales) among the articles is highly inconsistent. However, most studies on the internationalisation of family businesses also support the thesis that they are more likely to follow the traditional path of internationalisation. This means that family firms begin international activity from neighbouring markets, that is, where the psychic and geographic distance is small (Daszkiewicz, 2014; Daszkiewicz \& Olczyk, 2015). Next, along with the accumulation of knowledge and resources, family firms gradually expand their activities to more distant markets (Claver, Rienda, \& Quer, 2009; Kontinen \& Ojala, 2010; Pukall \& Calabro, 2014; Poór, Juhasz, Machova, Bencsik, \& Bilan, 2018). Moreover, Pukall and Calabro (2014) show that family businesses are generally internationalised according to the suggestions contained in the Dunning eclectic paradigm (Erdener \& Shapiro, 2005). Depending on the existence of differentiated advantages of ownership, internalisation, and location advantages, family firms select various types of entry modes, mainly foreign direct investment. Generally, family businesses choose those forms of entry to foreign markets that do not limit their independence.

In turn, Arregle et al. (2017) meta-analysis of 76 studies from 41 countries shows differences between countries in the family firms' relationship with internationalisation may be explained by the roles of family control, internationalisation types, and home country institutional conditions, such as minority shareholder protection.

Moreover, Sougata, Mondal, and Ramachandran (2018) claim that family ownership must exercise control over the firm's decisions and actions. Family often has the power and authority to impose noneconomic goals on the firm. On the other hand, families differ in their ability to control their firms, because concentration and involvement in management vary among families.

However, as in the case of non-family enterprises, exports are the most popular form of entry for family firms.

On the basis of literature and research review, De Massis Frattini, Majocchi, and Piscitello (2018) reveal that family firms are more likely to remain in their domestic markets and adopt conservative behaviours because of their strong connection to home regions and local roots. Moreover, family firms may have an aversion to risky behaviours in international markets. On the other hand, other scholars recently recognized family firms as the "important protagonist" of international entrepreneurship. De Massis De Massis, Frattini, Majocchi, and Piscitello indicate as the main incentives to embark on global initiatives the following: family involvement, emotional attachment to the firm, low-term orientation, lower agency costs, and higher endowment of social capital.

Moreover, the literature on international entrepreneurship suggests that some family businesses experience rapid growth caused by new generations of entrepreneurs (successors; Bell, McNaughton, Young, \& Crick, 2003; Graves \& Thomas, 2008). Such enterprises are referred to as born-again-global, and they represent various patterns of internationalisation. However, research in this area is still quite rare (Graves \& Thomas, 2004; Calabro \& Mussolino, 2013; Pukall \& Calabro, 2014; Sikora \& Baranowska-Prokop, 2018; Abidi, Antoun, Habibniya, \& Dzenopoljac, 2018). 
The majority of Polish researchers argue that family firms are less internationalised than other firms. However, some show that family firms listed on the stock exchange are more internationalised (Wach \& Wojciechowski, 2014; Wach, 2017). Daszkiewicz and Wach (2014) investigate 216 Polish firms, including 88 family businesses, to highlight that family firms in their expansion into foreign markets are mainly market seekers. Moreover, family firms much less frequently than non-family firms use advanced entry modes in their international expansion.

\section{MATERIAL AND METHODS}

This study conducted Empirical research on the internationalisation of high-tech firms operating in Poland at the end of 2015 with the use of Computer Assisted Telephone Interviewing (CATI) (see: Kobylińska, Rollnik-Sadowska, \& Samul, 2017). Random sampling was selected according to the following criteria about a firm (Daszkiewicz, 2019: (i) conducts international activity, (ii) belongs to one of the classes of activity (PKD; Polish Classification of Activities), namely "high-tech" or "medium-high-tech," (iii) fulfils at least one of the three following criteria:

- obtains patents or signs licensing agreements in areas considered high-tech,

- employs personnel with high scientific and technical qualifications,

- conducts industrial research or developmental works.

The survey obtained 263 fully completed questionnaires (the return rate was $8.2 \%$ ) relevant for further statistical processing.

The survey respondents were usually employees with managerial positions. In few cases, these were employees appointed by managers to give an interview as persons with adequate knowledge about the R\&D and international activities of the firm.

Calculations from the obtained survey results were made using Statistica ${ }^{\circledR}$ PL v. 10 software. In the survey, the level of statistical significance (alpha or $\alpha$ ) for testing the hypotheses was established at the level of $\alpha=0.05$, while the level $p<0.1$ was adopted as the acceptable level of non-rejection of the null hypothesis. Based on the obtained statistics, level $p$ was doubled to obtain a significant level $\alpha$ (Creswell, 2014, p. 169).

The following statistics were used to verify the formulated research hypotheses: Pearson's $\chi^{2}$ to examine the statistical significance of two-dimensional relationships between variables of qualitative character - non-rankable and rankable - Cramer's V contingency coefficient to examine the statistical strength of the relationship between qualitative variables for the cases, in which the relationships turned out to be significant, Spearman's rank correlation coefficient to examine the strength and the direction of the relationships between qualitative rankable variables, and T-test to compare two averages.

The literature studies resulted in the formulation of the following four hypothesis to be tested.

H1: Internationalisation intensity measured by the Transnationality Index is negatively correlated with firm familiness.

Various research findings differ on how the internationalisation of family firms may differ from that of non-family firms. For example, De Massis et al. (2018) shows that family 
firms are more likely to remain in their domestic markets and adopt conservative behaviours than non-family firms. Moreover, Kontinen and Ojala $(2010,2012)$ prove that the impact of familiness on different aspects of the internationalisation - including the degree of international sales - is highly inconsistent. However, most studies support the thesis that family firms are more likely to adopt traditional behaviours.

H2: Family firms are mainly market seekers when going international, as they are much more reactive on international markets.

H3: Family firms' rare comparison to non-family firms uses advanced investment modes of entry into international markets.

Family businesses usually choose those forms of entry to foreign markets that do not limit their independence, export remains the most popular form of entry of family firms as in the case of non-family enterprises (Pukall \& Calabro, 2014). Moreover, the research conducted in Poland by Daszkiewicz and Wach (2014) shows that family firms are mainly market seekers in their expansion into foreign markets and that they much less frequently use advanced entry modes in their international expansion than non-family firms.

H4: Internationalisation speed of a firm is negatively correlated with familiness.

Kontinen and Ojala (2010) claim that family firms are more likely to take a traditional path of internationalisation. They find evidence that internationalisation processes of family firms are more often gradual than in the case of non-family firms. Moreover, family firms tend to choose psychically close countries. The stepwise approach of family firms results from their long-term orientation to both business and family (Stieg et al., 2018; Brigham et al., 2014).

\section{RESULTS AND DISCUSSION}

The research sample includes firms of all size classes: micro, small, medium, and large. The share of SMEs among the surveyed firms is $82 \%$ (216 firms), while the share of large enterprises is $18 \%$ ( 47 firms). The survey was conducted in the whole territory of Poland.

Family enterprises account for $38.4 \%$ of surveyed enterprises while non-family enterprises for $61.6 \%$. Respondents received an explanation that family businesses are those that are mostly owned by the same family and in which family members are employed or the firm is at least supported by family members (Table 1 ).

Table 1. The size of surveyed firms

\begin{tabular}{|l|r|r|r|r|r|r|}
\hline \multirow{2}{*}{\multicolumn{1}{|c|}{ Size Class }} & \multicolumn{2}{|c|}{ Family Firms } & \multicolumn{2}{c|}{ Nom-Family Firms } & \multicolumn{2}{c|}{ Total } \\
\cline { 2 - 7 } & \multicolumn{1}{|c|}{ Obs. } & \multicolumn{1}{c|}{$\%$} & \multicolumn{1}{c|}{ Obs. } & \multicolumn{1}{c|}{$\%$} & \multicolumn{1}{c|}{ Obs. } & \multicolumn{1}{c|}{$\%$} \\
\hline Micro: (1-9 employees) & 9 & 8.9 & 15 & 9.3 & 24 & 9.1 \\
\hline Small: (10-49 employees) & 33 & 32.7 & 35 & 21.6 & 68 & 25.9 \\
\hline Medium: (50-249 employees) & 45 & 44.6 & 79 & 48.8 & 124 & 47.1 \\
\hline Large: (250+ employees) & 14 & 13.9 & 33 & 20.4 & 47 & 17.9 \\
\hline Total & 101 & 100.0 & 162 & 100.0 & 263 & 100.0 \\
\hline
\end{tabular}

Source: own study based on the survey $(n=263)$.

The survey included all industries, i.e. firms representing each industry are present in the research sample. The largest number of enterprises manufactures computers 
along with electronic and optical products (NACE 26), i.e. $13 \%$ of all the surveyed firms, while among the industries classified as medium high tech (MHT) most enterprises operate in the machinery and equipment industry, not classified elsewhere (NACE 28). The production of electrical equipment (NACE 27) amounts to $17 \%$ and the production of chemicals and chemical products (NACE 20) to $14 \%$ (see Table 2).

Table 2. Industries according to NACE

\begin{tabular}{|c|c|c|}
\hline Business activities/industries & Obs. & $\%$ \\
\hline \multicolumn{3}{|l|}{ High technologies (High-Tech, HT) } \\
\hline $\begin{array}{l}\text { NACE 21: Manufacturing of basic pharmaceutical substances and other pharmaceu- } \\
\text { tical products }\end{array}$ & 5 & 1.90 \\
\hline NACE 26: Manufacturing of computers, electronic and optical components & 34 & 12.93 \\
\hline NACE 30.3: Manufacturing of air and spacecraft and related machinery & 3 & 1.14 \\
\hline \multicolumn{3}{|l|}{ Medium technologies (Medium-High Tech, MHT) } \\
\hline NACE 20: Manufacturing of chemicals and chemical products & 37 & 14.07 \\
\hline NACE 25.4: Manufacturing of weapons and ammunition & 3 & 1.14 \\
\hline NACE 27: Manufacturing of other electrical equipment & 44 & 16.73 \\
\hline NACE 28: Manufacturing of special-purpose machinery not elsewhere classified & 111 & 42.21 \\
\hline NACE 29: Manufacturing of motor vehicles, trailers and semi-trailers excluding motorcycles & 16 & 6.08 \\
\hline NACE 30.2: Manufacturing of railway locomotives and rolling stock & 2 & 0.76 \\
\hline NACE 30.4: Manufacturing of military fighting vehicles & 1 & 0.38 \\
\hline NACE 30.9: Manufacturing of transport equipment not elsewhere classified & 10 & 3.80 \\
\hline NACE 32.5: Manufacturing of medical and dental instruments and supplies & 11 & 4.18 \\
\hline
\end{tabular}
Note: respondents could select more than 1 answer.

Source: own calculations $(n=263)$.

According to the SITC product classification (Standard International Trade Classification), most of the firms inclined towards the production of electrical machines (34\%), non-electrical machines (27\%), electronics and telecommunications (17\%), and chemicals (14\%; Table 3$)$.

Table 3. Activity according to SITC (product) classification

\begin{tabular}{|l|c|c|}
\hline \multicolumn{1}{|c|}{ Business activity } & Observations & $\%$ \\
\hline Space equipment & 2 & 0.76 \\
\hline Computer equipment & 3 & 1.14 \\
\hline Electronic-telecommunication & 46 & 17.49 \\
\hline Pharmaceuticals & 8 & 3.04 \\
\hline Scientific instruments & 9 & 3.42 \\
\hline Combustion vehicles & 16 & 6.08 \\
\hline Electrical machines & 89 & 33.84 \\
\hline Chemicals & 37 & 14.07 \\
\hline Non-electrical machines & 71 & 27.00 \\
\hline Ammunition and weapons & 2 & 0.76 \\
\hline Other & 7 & 2.66 \\
\hline
\end{tabular}

Note: respondents could select more than 1 answer.

Source: own calculations $(n=263)$. 


\section{Internationalisation Intensity}

The transnationality index (TNI) was calculated as the average of foreign foreign assets, foreign sales, and foreign employment to the total ones.

The average value of the TNI for the whole research sample $(n=263)$ is 20.6 , while the median is 13.33 , and the standard deviation equals 19.48 . It means that, on average, in a continuum from 0 to 100, the level of the internationalisation of firms in the sample is low.

Furthermore, the analysis of the TNI index value indicates that over $42 \%$ of firms in the sample has an internationalisation rate of less than 0.1 and nearly $75 \%$ less than 0.3 , which means that $75 \%$ of the surveyed enterprises are poorly internationalised.

The distribution of index values of the internationalisation index is extremely righthandedly asymmetric, as shown in the histogram below (Figure 1).

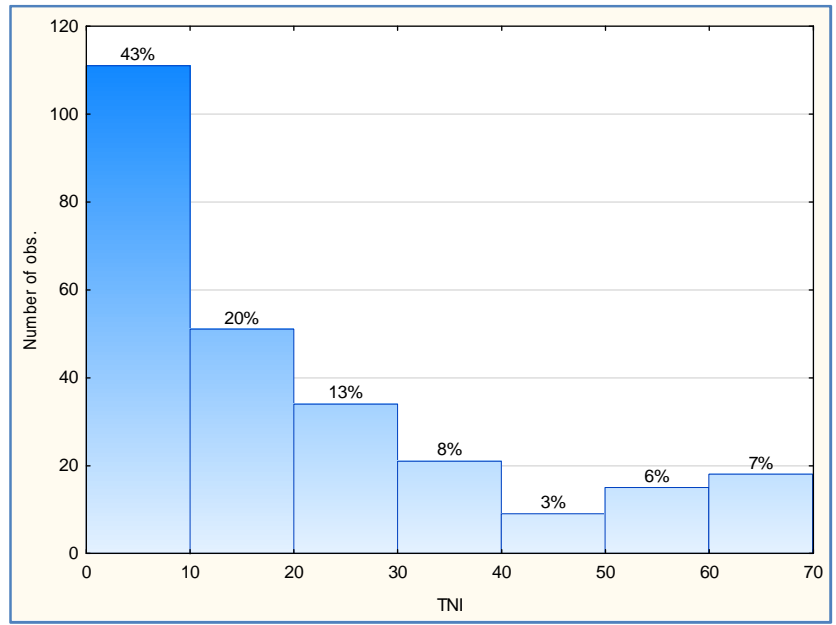

Figure 1. Distribution of TNI among the survey firms Source: own study based on the survey $(n=259)$.

Analysis showed that there is a statistically significant correlation of moderate force between the TNI and firm size $(\chi 2=25.948, d f=6, p=0.00023$, Spearman $R=0$. 254 , Cramer's V contingency coefficient $=0.224)$. This means that the size of the business increases as TNI grows.

For family businesses, the average value of the TNI is 17.23 , the median is 13.33 , and the standard deviation is 15.33 (Figure 2).

For non-family firms, the average value of the TNI index is 22.76 , the median is 15.17 , and the standard deviation is 21.50 (Figure 3).

The analysis showed that there is a statistically significant relationship of a weak strength between the TNI and firm familiness $(\chi 2=8.226387, \mathrm{df}=2, \mathrm{p}=0.01636$, R-Spearman $=0.174 \mathrm{~V}$-Cramer's contingency coefficient $=0.1772193)$. This means that the intensity of the internationalisation of family firms is lower than that of non-family enterprises. Thus, the first hypothesis is confirmed. 


\section{Internationalisation Motives}

To identify internationalisation motives, the study used a tool developed by Hansson and Hedin (2007). This tool consists of 28 questions that reflect the five main motivations for internationalisation in the extended Dunning concept: market seeking, resources seeking, efficiency seeking, strategic assets seeking, networks and co-operation seeking (Wach, 2016).

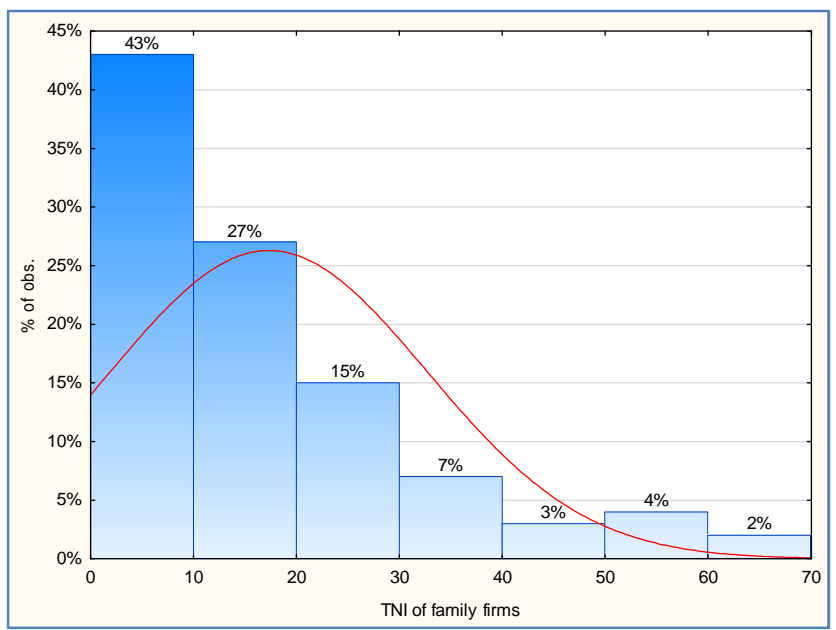

Figure 2. Distribution of the TNI index of the internationalisation of the family firms $(n=101)$ Source: own study based on the survey $(n=101)$.

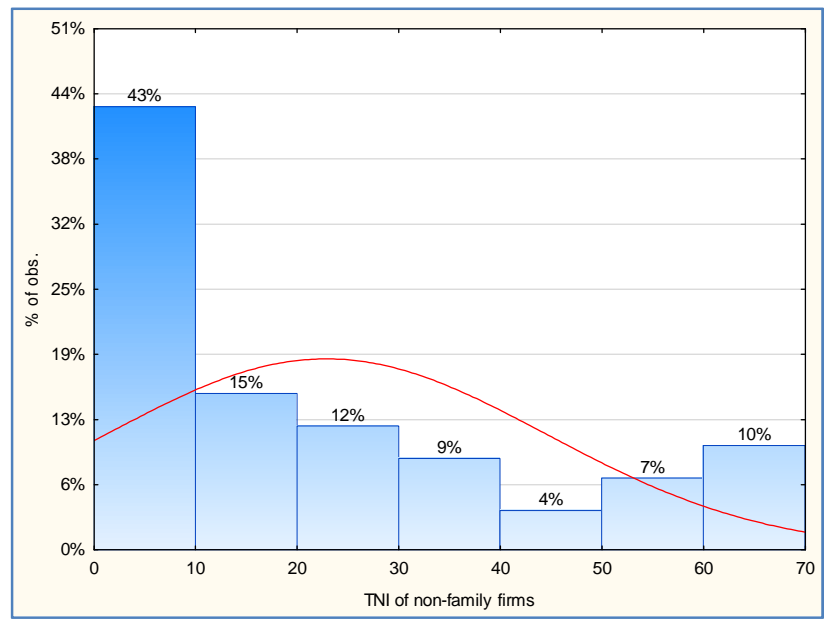

Figure 3. Distribution of the TNI index of the internationalisation of non-family firms ( $n=162$ ) Source: own study based on the survey.

Respondents were to assess the importance of the statements indicated on a fivepoint scale, in which 1 meant an unimportant motive and 5 a very important motive. 
Therefore, the survey results could be submitted in the form averaged for all surveyed enterprises with the use of a simple arithmetic mean tool (Table 4).

Table 4. Motives for internationalising according to Dunning's typology (on a five-point Likert scale)

\begin{tabular}{|c|c|c|c|}
\hline Factors & $\begin{array}{c}\text { Fa- } \\
\text { mily }\end{array}$ & $\begin{array}{c}\text { Non- } \\
\text { family }\end{array}$ & Total \\
\hline \multicolumn{4}{|l|}{ MARKET SEEKING } \\
\hline Protection / development of existing markets or market share & 4.5 & 4.4 & 4.4 \\
\hline Exploitation or entering new markets & 4.3 & 4.3 & 4.3 \\
\hline Better adaptation of products to foreign markets through physical presence & 3.8 & 3.8 & 3.8 \\
\hline First mover advantage & 3.5 & 3.3 & 3.5 \\
\hline Reduction of costs (transport, production) through presence on the local market & 3.5 & 3.2 & 3.4 \\
\hline The host country encourages FDI & 2.3 & 2.2 & 2.5 \\
\hline Avoiding barriers in trade (e.g. duties, quotas) & 2.8 & 2.6 & 2.9 \\
\hline Limited domestic market & 3.1 & 3.1 & 3.2 \\
\hline \multicolumn{4}{|l|}{ RESOURCE SEEKING } \\
\hline Better access to natural resources in the host country & 1.9 & 2.0 & 2.1 \\
\hline Better access to cheap and /or unqualified workforce in the host country & 1.9 & 1.8 & 2.0 \\
\hline Better infrastructure in the host country & 2.3 & 2.2 & 2.4 \\
\hline Better energy and water supply in the host country & 2.0 & 2.1 & 2.3 \\
\hline A more appropriate institutional and legal framework in the host country & 2.5 & 2.7 & 2.8 \\
\hline \multicolumn{4}{|l|}{\begin{tabular}{|l|} 
EFFICIENCY SEEKING \\
\end{tabular}} \\
\hline $\begin{array}{l}\text { The possibility of a later profit / benefit from the differences in supply and costs } \\
\text { (labour, resources) between countries }\end{array}$ & 2.7 & 2.9 & 3.0 \\
\hline $\begin{array}{l}\text { The possibility of a future profit / benefit from the differences in consumption } \\
\text { patterns between countries }\end{array}$ & 2.5 & 2.6 & 2.8 \\
\hline $\begin{array}{l}\text { The possibility of subsequent rationalization thanks to a shift in demand } \\
\text { among countries }\end{array}$ & 2.4 & 2.6 & 2.7 \\
\hline The possibility of future benefit from the economies of scale and scope & 2.7 & 2.9 & 3.1 \\
\hline Ability to lower the total tax burden while being in more than one country & 2.5 & 2.7 & 2.8 \\
\hline \multicolumn{4}{|l|}{ STRATEGIC ASSETS SEEKING } \\
\hline $\begin{array}{l}\text { Acquisition of another company or part of another company in order to gain } \\
\text { knowledge about foreign markets }\end{array}$ & 2.0 & 1.8 & 2.1 \\
\hline $\begin{array}{l}\text { Acquisition of another company or part of another company in order to acquire } \\
\text { technological knowledge (patents, employee skills, systems) }\end{array}$ & 2.1 & 1.9 & 2.3 \\
\hline Acquisition of another company or part of another company to limit competition & 2.0 & 1.8 & 2.2 \\
\hline $\begin{array}{l}\text { Acquisition of another company or part of another company to stop competi- } \\
\text { tors from acquiring this company }\end{array}$ & 1.9 & 1.8 & 2.1 \\
\hline Better access to qualified and educated workforce & 3.1 & 2.7 & 3.1 \\
\hline \multicolumn{4}{|l|}{ NETWORKS AND CO-OPERATION SEEKING } \\
\hline $\begin{array}{l}\text { Increased opportunity to acquire technology, knowledge in the field of manage- } \\
\text { ment / or marketing, organizational skills }\end{array}$ & 2.9 & 2.8 & 3.0 \\
\hline The ability to follow or stay close to major customers / suppliers & 3.4 & 3.3 & 2.4 \\
\hline Better use of resources belonging to partners & 2.8 & 2.9 & 3.0 \\
\hline The exploitation of cluster effects & 1.4 & 1.2 & 2.4 \\
\hline The beginning of a new cooperation & 3.9 & 4.0 & 4.0 \\
\hline
\end{tabular}

Source: own study based on the survey $(n=263)$. 
In order to check the existence of significant differences between family and nonfamily firms in their internationalisation motives, a Student's t-test for averages was performed, assuming the independence of attempts and equality of variances in compared groups of firms.

The t-test that compared the variances between groups of family and non-family enterprises showed in each case that $p>\alpha(\alpha=0.05)$, therefore we may assume the equality of variances. This enables a reliable t-test for the average of all types of motives tested. The results of this test show that $p$-value for all examined motives is greater than the significance level $\alpha=0.05$, which allows us to assume no differences between family and nonfamily companies for each motive. Thus, the second hypothesis is rejected.

\section{Entry Modes}

Foreign entry mode choice is an important strategic decision for a firm, as it determines the level of its resource commitment along with the risk and the nature of control it has over its foreign activities in the host country (Arregle, Hébert, \& Beamish, 2006; Alnassar, 2017).

This article accepts the criteria proposed by Hollensen (2010), who identifies three categories of foreign entry modes according to the level of control criteria (Daszkiewicz, 2017):

1. High control modes: (i) foreign direct investment (FDI) in the form of wholly owned subsidiaries (WOS), (ii) direct selling to big customers (OEMs). These entry modes are equal to full control with activities in foreign markets.

2. Intermediate modes: (i) strategic alliances (SA), (ii) joint ventures (JV). These entry modes are located in-between high and low control modes; partners usually share resources, technology, profits, and jobs; the local partner usually provides marketspecific knowledge.

3. Low control modes: (i) indirect export, (ii) direct export. The level of control is the lowest in the case of indirect export, when a parent company uses independent organizations located in the parent company's own country or third country. In the case of direct export, the parent firm sells directly to an agent, distributor, or importer located in the foreign market, which provides a higher degree of control than indirect export.

In order to check whether there is a significant relationship between entry modes and whether the firm is family or non-family owned, I calculated V-Cramer contingency ratios and R-Spearman correlation coefficients for each type of entry modes $\chi^{2}$ statistics. For each type of entry modes, it turned out that $p$-value for $\chi^{2}$ is greater than the level of significance $\alpha(\alpha=0.05)$. This result allows assuming that there is no significant relationship between familiness and the choice of entry mode. Similar results produced R-Spearman correlation coefficients. In each of the studied cases, correlation coefficients are close to zero, while $p$-value for each of the calculated coefficients is greater than the level of significance $\alpha$ $(\alpha=0.05)$. This confirms the results presented above. Thus, the third hypothesis is rejected.

\section{Internationalisation Speed}

Most of authors define early internationalisation as a number of years from the inception to the beginning of international sales: firms which start exporting (or any other entry mode) in the first three years are classified as early international firms (EIFs). Moreover, this article accepted three years as the borderline separating the traditional from the early 
and rapid internationalisation (Knight \& Cavusgil, 2004; Zuchella, Palamara, \& Denicolai, 2007, Wach, 2015; Pohlova et al., 2018).

In the sample, $45 \%$ of the surveyed firms can be classified - according to the classification - as born global, i.e. firms that have taken their first expansion on foreign markets less than three years after establishment. In the case of $55 \%$ of the surveyed firms, the first expansion happened more than three years after the establishment of the firm, which was a traditional path (Table 5).

Table 5. The Internationalisation speed of the investigated firms

\begin{tabular}{|l|c|c|}
\hline \multicolumn{1}{|c|}{ Type of Firm } & $\begin{array}{c}\text { Up to Three Years } \\
\text { from the Inception }\end{array}$ & $\begin{array}{c}\text { More Than Three Years } \\
\text { from the Inception }\end{array}$ \\
\hline Family firms & 38 & 63 \\
\hline Non-family firms & 79 & 79 \\
\hline Total & 117 & 142 \\
\hline
\end{tabular}

Source: own study based on the survey $(n=259)$.

The analysis showed that there is a statistically significant relationship between familiness and internationalisation speed $(\chi 2=3.810494$, df $=1, p=0.05093$, Spearman $R=-0.121294$, Cramer's contingency $V=0.1204119)$. It is a dependence of weak strength. Therefore, family businesses are less likely to internationalise early than in the case of nonfamily enterprises. Thus, the fourth hypothesis is confirmed.

Based on the calculations it was possible to accept two hypotheses and reject two other hypotheses (see Table 6).

Table 6. Hypotheses verification

\begin{tabular}{|l|l|c|l|}
\hline \multicolumn{2}{|c|}{ Hypothesis } & Verification status & Verification method \\
\hline H1: & $\begin{array}{l}\text { Internationalisation intensity measured by } \\
\text { the Transnationality Index is negatively cor- } \\
\text { related with firm familiness. }\end{array}$ & confirmed & $\begin{array}{l}\text { Pearson's } \chi^{2} \\
\text { Cramer's V contingency } \\
\text { coefficient, Spearman R }\end{array}$ \\
\hline H2: & $\begin{array}{l}\text { Family firms are mainly market seekers } \\
\text { while going international, as they are much } \\
\text { more reactive on international markets. }\end{array}$ & rejected & Student's t-test \\
\hline H3: & $\begin{array}{l}\text { Family firms' rare comparison to non-family } \\
\text { firms uses advanced investment modes of } \\
\text { entry into international markets. }\end{array}$ & rejected & $\begin{array}{l}\text { Pearson's } \chi^{2} \\
\text { Cramer's V contingency } \\
\text { coefficient, Spearman R }\end{array}$ \\
\hline H4: & $\begin{array}{l}\text { Internationalisation speed is negatively cor- } \\
\text { related with firm familiness. }\end{array}$ & $\begin{array}{l}\text { Pearson's } \chi^{2} \\
\text { Cramer's V contingency } \\
\text { coefficient, Spearman R }\end{array}$ \\
\hline
\end{tabular}

Source: own elaboration.

\section{CONCLUSIONS}

The main aim of this study was to present internationalisation patterns of family firms, especially their intensity, motives, speed, and entry modes.

The key results of the empirical research show that the intensity of the internationalisation of family firms was lower than that of non-family enterprises and that family businesses are less likely than non-family enterprises to internationalise early. On the other 
hand, I found no differences between family and non-family businesses in their entry modes choice and internationalisation motives. Thus, the study supports the thesis that family firms are more likely to choose a traditional, stepwise path of internationalisation, which is slower than that of non-family firms.

Despite confirming only two out of four hypotheses, the research results support others studies that claim the internationalisation of family firms may differ from that of non-family firms, especially because family firms are more likely than non-family firms to adopt conservative behaviours and to follow a traditional path of internationalisation (Kontinen \& Ojala, 2010; De Massis et al., 2018).

The research was conducted on a sample of 263 enterprises operating in high-tech and medium high-tech industries, including 101 family businesses. The main limitation of this study is the lack of representativeness of the research sample. Thus, the research results cannot be generalized to other high-tech family businesses in Poland.

However, the research sample is acceptable for Polish conditions, comparing to similar empirical research. Moreover, the research covered firms that operate throughout the country in all high-tech and medium high-tech industries, which means that enterprises from every industry are present in the research sample.

Furthermore, the obtained results indicate possible further research directions. In regard to the examination of differences in internationalisation factors between family and non-family high-tech firms, I believe that further research should address family firms from the perspective of international entrepreneurship. International entrepreneurship literature calls some family firms born-again globals, who represent various patterns of internationalisation, so the role of the family in international entrepreneurship is not sufficiently recognized and requires further research (Wach, 2017).

Taking into account that this research concerns high-tech firms, which often use knowledge as their core competence, further research could also focus on the role of knowledge in the internationalisation processes of family firms. Moreover, knowledge is crucial for the development of not only businesses but also economies. Furthermore, knowledge is also used as an important variable to explain the process of firm internationalisation (Daszkiewicz \& Olczyk, 2015).

The article may be valuable for students and PhD students who explore the field of international business and entrepreneurship. It may also support entrepreneurs, in particular owners and managers of family firms.

\section{REFERENCES}

Abidi, O., Antoun, R., Habibniya, H., \& Dzenopoljac, V. (2018). Firm-specific determinants of FDI from GCC to MENA countries. Journal of International Studies, 11(4), 9-21. doi:10.14254/20718330.2018/11-4/1

Alnassar, F. (2017). Franchising and the internationalization of businesses: the case of fast food chains. International Entrepreneurship Review, 3(2), 23-36. https://doi.org/10.15678/PM.2017.0302.02

Arregle, J.L., Duran, P., Hitt, M.A., \& Van Essen, M. (2017). Why is family firms' internationalization unique? A meta-analysis. Entrepreneurship Theory and Practice, 41(5), 801-831.

Arregle, J.L., Hébert, L., \& Beamish, P.W. (2006). Mode of international entry: The advantages of multilevel methods. Management International Review, 46(5), 597-618. 
Bell J., McNaughton R., Young S., \& Crick D. (2003). Towards an integrative model of small firm internationalisation. Journal of International Entrepreneurship, 1(4), 339-362.

Brigham, K.H., Lumpkin, G.T., Payne, G.T., \& Zachary, M.A. (2014). Researching long-term orientation: A validation study and recommendations for future research. Family Business Review, 27(1), 72-88.

Calabrò, A., \& Mussolino, D. (2013). How do boards of directors contribute to family SME export intensity? The role of formal and informal governance mechanisms. Journal of Management \& Governance, 17(2), 363-403.

Chalupová, M., Rojík, S., Pilař, L., \& Prokop, M. (2019). Factors affecting food purchases in vysočina region with focus on regional food. Agris on-Line Papers in Economics and Informatics, 11(3), 35-44. doi:10.7160/aol.2019.110304

Claver, E., Rienda, L., \& Quer, D. (2009). Family firm's international commitment: The influence of family related factors. Family Business Review, 22(2), 125-135.

Creswell, J.W. (2014). Research Design: Qualitative, Quantitative and Mixed Methods Approaches. Los Angeles, CA: SAGE Publications Inc.

Crick, D., Bradshaw, R., \& Chaudhry, S. (2006). Successful internationalising UK family and nonfamily-owned firms: A comparative study. Journal of Small Business and Enterprise Development, 13(4), 498-512.

Daszkiewicz, N. (2014). Internacjonalizacja polskich przedsiębiorstw rodzinnych z perspektywy przedsiębiorczości międzynarodowej. Przedsiębiorczość i Zarzq̨dzanie, 15(7), 243-252.

Daszkiewicz, N. (2017). Foreign entry modes of high-tech firms in Poland. Studia Universitatis BabesBolyai, Negotia, 62(2), 23-34.

Daszkiewicz, N. (2019). The internationalisation of high-tech firms. In N. Daszkiewicz (Ed.), The Internationalization of High-Tech Firms: Patterns, Innovation and Research and Development. Cambridge: Cambridge Scholars Publishing, pp. 36-64.

Daszkiewicz, N., \& Olczyk, M. (2015). Determinants of the internationalization of family firms-a structural equation modeling analysis. Przedsiębiorczość i Zarzq̨dzanie, 16(7), 11-30.

Daszkiewicz, N., \& Wach, K. (2014). Motives for going international and entry modes of family firms in Poland. Journal of Intercultural Management, 6(2), 5-18.

Davis, P.S., \& Harveston, P.D. (2000). Internationalisation and organisational growth: The impact of internet usage and technology involvement among entrepreneur-led family businesses. Family Business Review, 13(2), 107-120.

De Massis, A., Frattini, F., Majocchi, A., \& Piscitello, L. (2018). Family firms in the global economy: Toward a deeper understanding of internationalization determinants, processes, and outcomes. Global Strategy Journal, 8(1), 3-21.

Erdener C., \& Shapiro D.M. (2005). The internationalization of Chinese family enterprises and Dunning's eclectic MNE paradigm. Management and Organization Review, 1(3), 411-436.

Głodowska, A., Pera, P., \& Wach, K. (2019). International Strategy as the Facilitator of the Speed, Scope, and Scale of Firms' Internationalization. Central European Management Journal, 27(3), 55-84.

Graves C., \& Thomas, J. (2008). Determinants of the internationalization pathways of family firms: An examination of family influence. Family Business Review, 21(2), 151-167.

Graves, C., \& Shan, Y.C. (2014). An empirical analysis of the effect of internationalization on the performance of unlisted family and nonfamily firms in Australia. Family Business Review, 27(2), 142-160.

Hadryś-Nowak, A. (2018). Family Entrepreneurship Orientation in Family Owned SMEs: A Key Resource for Internationalization?. Entrepreneurial Business and Economics Review, 6(2), 153-169. 
Hallová, M., Polakovič, P., Šilerová, E., \& Slováková, I. (2019). Data protection and security in SMEs under enterprise infrastructure. Agris on-Line Papers in Economics and Informatics, 11(1), 2733. https://doi.org/10.7160/aol.2019.110103

Hanson, A., \& Hedin, K. (2007). Motives for internationalization: Small companies in Swedish incubators and science parks (master's thesis). Uppsala University, Upsala, Sweden.

Hollensen, S. (2010). Global Marketing - A decision-oriented approach, 5th edition. Pearson: Harlow, UK.

Johanson, J., \& Vahlne, J.E. (1977). The internationalization process of the firm-a model of knowledge development and increasing foreign market commitments. Journal of International Business Studies, 8(1), 23-32.

Knight, G.A., \& Cavusgil, S.T. (2004). Innovation, organizational capabilities, and the born-global firm. Journal of International Business Studies, 35(2), 124-141.

Kobylińska, U., Rollnik-Sadowska, E., \& Samul, J. (2017). Young people on the labour market in Poland - the point of view of the employer. Oeconomia Copernicana, 8(4), 553-568.

Kontinen T., \& Ojala A. (2012). Internationalization pathways among family-owned SMEs. International Marketing Review, 29(5), 496-518.

Kontinen T., \& Ojala, A. (2010). The internationalization of family businesses: A review of extant research. Journal of Family Business Strategy, 1(2), 97-107.

Kontinen, T., \& Ojala, A. (2011). Network ties in the international opportunity recognition of family SMEs. International Business Review, 20, 440-453.

Labaki, R. (2011). The Financial Behaviour of Families in Business. In K. Surdej \& K. Wach (Eds.), Managing Ownership and Succession in Family Firms, Scholar, Warsaw.

Lušňáková, Z., Juríčková, Z., Šajbidorová, M., \& Lenčéšová, S. (2019). Succession as a sustainability factor of family business in Slovakia. Equilibrium. Quarterly Journal of Economics and Economic Policy, 14(3), 503-520.

Marjański, A., \& Sułkowski, Ł. (2019). The Evolution of Family Entrepreneurship in Poland: Main Findings Based on Surveys and Interviews from 2009-2018. Entrepreneurial Business and Economics Review, 7(1), 95-116.

O'Boyle, E.H., Pollack, J.M., \& Rutherford, M.W. (2012). Exploring the relation between family involvement and firms' financial performance: A meta-analysis of main and moderator effects. Journal of Business Venturing, 27(1), 41-42.

Pohlová, K., Smutka, L., Laputková, A., \& Svatoš, M. (2018). Czech agrarian foreign trade according to the degree of processing. Agris on-Line Papers in Economics and Informatics, 10(3), 103-118. https://doi.org/10.7160/aol.2018.100309

Poór, J., Juhász, T., Machová, R., Bencsik, A., \& Bilan, S. (2018). Knowledge management in human resource management: Foreign-owned subsidiaries' practices in four CEE countries. Journal of International Studies, 11(3), 295-308. doi:10.14254/2071-8330.2018/11-3/23

Pukall T.J., \& Calabrò A. (2014). The internationalization of family firms: A critical review and integrative model. Family Business Review 27( 2), 103-125.

Sciascia, S., Mazzola, P., Astrachan, J.H., \& Pieper, T.M. (2012). The role of family ownership in international entrepreneurship: Exploring nonlinear effects. Small Business Economics, 38(1), 15-31.

Sikora, T., \& Baranowska-Prokop, E. (2018). Explaining success perception of Polish international new ventures: Four perspectives. Economics and Sociology, 11(4), 106-127. doi:10.14254/2071-789x.2018/11-4/7

Sougata, R., Mondal, A., \& Ramachandran, K. (2018). How does family involvement affect a firm's internationalization? An investigation of Indian family firms. Global Strategy Journal, 8(1), 73-105. 
Stieg, P., Cesinger, B., Apfelthaler, G., Kraus, S., \& Cheng, C.F. (2018). Antecedents of successful internationalization in family and non-family firms: How knowledge resources and collaboration intensity shape international performance. Journal of Small Business Strategy, 28(1), 14-27.

Thomas, J., \& Graves, C. (2005). Internationalising the family firm as a demonstration of an entrepreneurial culture. Journal of Small Business and Entrepreneurship, 17(2), 91-113.

Tsao, S.M., \& Lien, W.H. (2013). Family management and internationalization: The impact on firm performance and innovation. Management International Review, 53(2), 189-213.

Verbeke, A., Yuan, W., \& Kano, L. (2018). A values-based analysis of bifurcation bias and its impact on family firm internationalization. Asia Pacific Journal of Management, 1-29.

Wach, K. (2016). Motywy internacjonalizacji przedsiębiorstw z branży high-tech: wstępne wyniki badań sondażowych. Przedsiębiorczość i Zarzq̨dzanie, XVII(10[1]), 93-107.

Wach, K. (2017). Exploring the Role of Ownership in International Entrepreneurship: How does Ownership Affect Internationalisation of Polish Firms?. Entrepreneurial Business and Economics Review, 5(4), 205-224.

Wach, K., \& Wojciechowski, L. (2014). The Size and the Strategic International Orientation: The Use of EPRG Model among Polish Family and Non-Family Firms. Przedsiębiorczość $i$ Zarzq̨anie, 15(7), 143-156.

Weclawski, J., \& Zukowska, B. (2019). Refreshing Typologies Based on Family Firms' Goals: The Perspective of "First-Generation Enterprises" Central European Management Journal, 27(3), 128-146.

Zahra, S.A. (2005). Entrepreneurial risk taking in family firms. Family Business Review, 18, 23-40.

Zahra, S.A. (2003). International expansion of U.S. manufacturing family businesses: The effect of ownership and involvement. Journal of Business Venturing, 18(4), 495-512.

Zucchella, A., Palamara, G., \& Denicolai, S. (2007). The drivers of the early internationalization of the firm. Journal of World Business, 42(3), 268-280. 


\section{Author}

\section{Nelly Daszkiewicz}

Professor at the Faculty of Management and Economics, Department of Economic Sciences, Gdansk University of Technology (Poland). Her research interests include the internationalisation of firms, international business, small and medium-sized enterprises, the competitiveness of firms, and European economic integration.

Correspondence to: Prof. dr hab. Nelly Daszkiewicz, Gdańsk University of Technology, Faculty of Management and Economics, ul. Narutowicza 11/12, 80-233 Gdańsk, Poland, e-mail: nelly.daszkiewicz@zie.pg.gda.pl

ORCID (1) http://orcid.org/0000-0001-6620-627X

\section{Acknowledgements and Financial Disclosure}

This article came into being within the research project OPUS entitled, "Internationalisation of small and medium-sized enterprises operating in high tech industries," which has been funded by the National Science Centre (NCN) on the basis of decision no. DEC-2013/11/B/HS4/02135 in 2014-2018.

\section{Copyright and License}

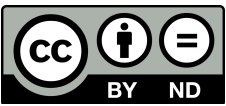

This article is published under the terms of the Creative Commons

Attribution - NoDerivs (CC BY-ND 4.0) License http://creativecommons.org/licenses/by-nd/4.0/

\section{Published by the Centre for Strategic and International Entrepreneurship - Krakow, Poland}


